The Aphid Genus Periphyllus

A Systematic, Biological and Ecological Study. By Prof. E. O. Essig and Frieda Abernathy. Pp. ix + 166. (Berkeley and Los Angeles: University of California Press; London: Cambridge University Press, 1952.) 22s. 6d. net.

TN a family of insects remarkable for the variety of forms which may be assumed by a species during the course of a single life-cycle, the aphid genus Periphyllus van der Hoeven is peculiar in that most of its members produce, in addition, specialized æstivating larvæ which remain in the first instar from the spring until the autumn, when growth and development are resumed. The members of this genus are nearly all confined to trees of the maple family, on which they complete their life-cycles.

This book embodies the results of six years of study of a number of American species of Periphyllus, and includes descriptions of others from Europe and eastern Asia. In their accounts of species which they have been able to study at first hand, the authors have contributed materially to our knowledge of this group, and, with the aid of copious illustrations, have shown the remarkable degree of variation in form which can occur during the life-cycle of a single species. The inclusion of lists of synonyms, host plants, notes on history and distribution, together with an impressive bibliography, usefully brings together a quantity of relevant material within the compass of a single volume. But in their survey of the genus as a whole, it is disappointing that the authors appear to have overlooked some important contributions from European workers. There is no mention of the recent work of Börner, nor of Hille Ris Lambers's very full and detailed account of the known European species of Periphyllus (Tijdschr. Ent., 88, 225 ; 1947).

In an otherwise attractively produced book, it is difficult to understand why most of the numerous line-drawings have been reproduced in half-tone, a process which, besides obscuring important anatomical details, does much less than justice to Frieda Abernathy's fine draughtsmanship. J. P. DonCASTER

\section{Amino Acids and Proteins}

Theory, Methods, Application. Compiled and edited by Prof. David M. Greenberg. Pp. ix+950. (Springfield, Ill.: Charles C. Thomas ; Oxford: Blackwell Scientific Publications, Ltd., 1951.) 110s. net.

THIS is an omnibus volume intended "to acquaint students and investigators with the more general methods employed in the study of the proteins, and to give a summary of the current knowledge and advances of the subject matter'. Its aim is therefore nothing less than a comprehensive treatment of amino-acids and proteins from the physico-chemical, organic and biochemical points of view. There is, in fact, no marked emphasis on any particular aspect; there are four chapters on the organic chemistry of amino-acids and peptides, two on the organic chemistry of proteins; three on the physical chemistry, and four on biochemical topics. Most of the major lines of protein research are represented; there is, however, little about the determination of the sequence of amino-acids in proteins, and nothing about specific chain-configurations.

In a book of such scope, with a multiplicity of authors, it is almost inevitable that the treatment should be uneven and perhaps inadequate in parts. The accounts of paper chromatography and peptide synthesis are, for example, well below the average standard of the work. A rather more serious criticism is that the text is not always as up to date as one would wish. In my opinion the book does, however, succeed in bringing to the reader, in the form of a series of separate essays, a large amount of information, some of which is not readily available elsewhere. The numerous tabulations of data are a particularly praiseworthy feature. I have no doubt that students and investigators will find the book useful. It is very well produced, and contains remarkably few misprints.

Sound

C. H. BAMFORD

An Advanced Course. By Dr. H. F. Boulind. Pp. vii + 104. (London: John Murray, Ltd., 1952.) 6s. $T \mathrm{~T}$ is difficult to believe that a small book of a hundred pages on sound can cover adequately the required ground for all stages of the sixth form and up to university scholarship-level, no previous knowledge of the subject being assumed. This, however, is what is claimed for this book which, on the whole (and understandably in the circumstances), is rather utilitarian in its approach, with one eye constantly on the examination question.

One has a great deal of sympathy with the author in his admission that his chief aim is to produce a book at a cost within the financial allocation for sixth forms. But surely the correct approach is to supply a really satisfying account of the subject, especially in sound, which has for so long been neglected, and then press the authorities to bring the allocation more in accord with present prices. Sixth-form and scholarship students certainly need, and deserve to have, a full and comprehensive volume for their studies, and it is high time that this serious defect on the part of those responsible was rectified.

What is done in this book is, as is to be expected, done well. The mathematics is well within the scope of the students for whom the book is intended, and there is an excellent set of graded questions. It is a pity that a bigger quantity of information of the same high quality could not be included.

\section{Gods, Graves and Scholars}

The Story of Archæology. By C. W. Ceram. Translated from the German by E. B. Garside. Pp. xiit $433+32$ plates. (London: Victor Gollancz, Ltd., in association with Sidgwick and Jackson, Ltd., 1952.) 21s. net.

THIS book is not intended for the specialist in prehistoric archæology; it is rather meant to fascinate the ordinary intelligent reader and to inspire him to delve more deeply into the subject. The author describes in graphic language the story of the discovery of several different sites in a number of localities; for example, he relates the earliest discovery of, and the first explorations at, such city sites as Pompeii, Troy, Mycenæ and Crete, and the origins of Egyptology. Again, the unearthing of Nineveh is recounted, as well as how the deciphering of Babylonian writings took place. The New World is not forgotten, and there is an exciting chapter on the empires of the Toltecs, the Aztecs and the Mayas. The historical approach to the subject is a good one and will undoubtedly excite many readers to dig more deeply into its problems, and the book can therefore be recommended. But even on the historical side it does not pretend to do more than dip into the subject here and there; it does not cover the ground as does such a work as Daniel's "Hundred Years of Archæology". None the less, it makes good reading. The translation runs smoothly. M. C. BuRKITT 